\title{
Detection of some antibiotic resistant genes within Salmonella serovars isolated from broiler chickens
}

\section{Mahmoud Ezzat ${ }^{1}$, Mahmoud Elsotohy ${ }^{2}$, Abo Elkheir Esawy ${ }^{2}$, Ali Wahdan ${ }^{1}$}

${ }^{1}$ Department of Bacteriology, Immunology and Mycology, Faculty of Veterinary Medicine, Suez Canal University, 41522 Ismailia, Egypt. ${ }^{2}$ Animal Health Research Institute, Bacteriology, Immunology and Mycology department, Mansoura branch, Egypt.

*Mahmoud Ezzat.... Email: mezzat05@yahoo.com

* Mahmoud Elsotohy.... Email: medo_sotohy2005@yahoo.com

* Abo Elkheir Esawy.... Email: esawy55@ gmail.com

* Ali Wahdan.... Email: dr_aly_w@yahoo.com

\begin{abstract}
:
This study aimed to examine the sensitivity of different antibiotics against 10 Salmonella serovars isolated previously from broiler farms. After that, all resistant serovas were detected genetically for the presence of qnrA, blaTEM, tetA (A) and $a a d B$ resistant genes. Two $S$. Typhimurium, one $S$. Kentucky, one $S$. Newport, one $S$. Tamale, one $S$. Enteritidis, one $S$. Molade, one $S$. Takoradi, one $S$. Virchow and one $S$. Inganda were examined sensitivity against different antibiotics by disc diffusion method. The resistant serovars to quinolones, $\beta$ lactams, gentamycin and doxycyclin were confirmed genetically. $S$. Kentucky, $S$. Tamale, $S$. Molade, $S$. Typhimurium and $S$. Takoradi were resistant to quinolones and carrying qnrA gene. $S$. Tamale, $S$. Inganda, $S$. Typhimurium, $S$. Newport, $S$. Molade, $S$. Typhimurium, $S$. Enteritidis, $S$. Takoradi and $S$. Virchow were resistant to $\beta$ lactams and carrying blaTEM gene. S.Tamale, $S$. Inganda, $S$. Typhimurium, $S$. Newport, $S$. Molade, $S$. Enteritidis and $S$. Virchow were resistant to doxycyclin and carrying tetA (A) gene. $S$. Typhimurium, $S$. Enteritidis and $S$. Takoradi were resistant to gentamycin and carrying aadB gene. The results showed that emerging of multidrug resistant strains to common antibiotics in the poultry field required newly discovered herbal compounds for control the disease and prevent the resistant phenomena.
\end{abstract}

Keywords: Salmonella serovars, antibiotic sensitivity, broilers, multidrug resistant. 
Introduction:

Poultry wealth is considered an important sector in national economy in Egypt on the one hand it represents a large part of the food security and on other hand, a source of employment in the poultry companies. Salmonellosis is an important health problem and a major challenge worldwide. Salmonella spp. are recognized as the most causative agents of food poisoning. (Gallegos et al., 2008). Multiple drug resistance genes have been found to be clustered on individual mobile elements, which mean that multi-resistance can be readily transferred and increase the multi-drug resistant bacterial population Nikaido (2009). ElSharkawy et al. (2017) reported that all $S$. Enterica serovar Enteritidis isolates were susceptible to all tested antimicrobials (tetracycline, ampicillin, sulfamethoxazole/trimethoprim, gentamicin, streptomycin and chloramphenicol).

The phenotypically resistant $S$. Enterica serovar Typhimurium isolates against ampicillin, tetracycline, sulphamethoxazole and chloramphenicol were harbouring blaTEM, (tetA and tet $\mathrm{C})$, (sul 1 and sul 3 ) and (cat 1 and floR), respectively. The sensitivity rate of $S$. Enteric serovar Typhimurium to gentamycin,

trimethoprim/sulphamethoxazole and streptomycin were 100, 94.8, and $89.7 \%$, respectively.
Recently, a basic role in dissemination and evolution of antimicrobial resistance in MDR $S$. Typhimurium DT104(MDRDT104) and many other organisms has been attributed to integrons, gene expression elements that potentially account for rapid and efficient transmission of drug resistance because of their mobility and ability to collect resistance gene cassettes; (Tosini et al., 1998). So, this study aimed to detect the encoding genes responsible for antibiotic resistance by using PCR.

\section{Material and methods:}

Bacterial isolation: A total of 10 Salmonella serovars $(2 \quad S$. Typhimurium, $1 S$. Kentucky, $1 S$. Newport, $1 S$. Tamale, $1 S$. Enteritidis, $1 S$. Molade, $1 S$. Takoradi, $1 S$. Virchow and $1 S$. Inganda were recovered previously from broilers farms from different internal organs. All isolates were previously handled and isolated from different farms in Dakahlia Governorate and the clinically examined birds showed signs of septicemia, retarded growth, depression, profuse watery white diarrhea and accumulation of fecal matter around the vent.

Identification of recovered isolates: Each isolate was inoculated separately in selenite $\mathrm{F}$ broth and incubated at $37^{\circ} \mathrm{C}$ for not more than 18 hours and rappaportvassiliadis soya broth incubated at $42^{\circ} \mathrm{C}$ for 24 hours. A loopful from the enrichment culture was streaked 
onto the surface of Xylose Lysine Deoxycholate (XLD) media and Salmonella Shigella agar (S-S agar) then incubated at $37^{\circ} \mathrm{C} \pm 1^{\circ} \mathrm{C}$ for 24hrs \pm 2hrs. Each colony was identified morphologically and biochemically according to Quinn et al., (2002).

Antibiotic sensitivity testing according to ISO 6579 (2002) method:

Determination of the susceptibility of the isolated strains to antimicrobial discs was adopted using the disc diffusion technique according to Finegold and Martin (1982).

PCR detection of antibiotic resistant genes

PCR assay was done to detect antibiotic resistance genes in the isolates. The isolates that showed resistance to antimicrobial agents in sensitivity tests for quinolones were examined for the presence of $q n r \mathrm{~A}$ gene while the isolates that showed resistance to $\beta$ lactams were examined for the presence of blaTEM gene. The isolates that showed resistance to doxycyclin were examined for tetA (A) gene. The isolates that showed resistance to gentamycin were examined for the presence of $a a d \mathrm{~B}$ gene. QIAamp DNA Mini Kit used for extraction of DNA. Primers used were shown in table (1). Temperature and time conditions of the primers during PCR are shown in table (2). Electrophoresis grade agarose $(1 \mathrm{~g})$ was prepared in 100 $\mathrm{ml}$ TBE buffer in a sterile flask, it was heated in microwave to dissolve all granules with agitation, and allowed to cool at $70^{\circ} \mathrm{C}$, then $0.5 \mu \mathrm{g} / \mathrm{ml}$ ethedium bromide was added and mixed thoroughly according to (Sambrook et al., 1989).

Table (1): Primers of tested antibiotic resistance genes.

\begin{tabular}{|c|c|c|c|}
\hline Primer & Sequence & $\begin{array}{l}\text { Amplified } \\
\text { product }\end{array}$ & Reference \\
\hline \multirow[t]{2}{*}{ bla TEM } & ATCAGCAATAAACCAGC & \multirow[t]{2}{*}{$516 \mathrm{bp}$} & \multirow{2}{*}{$\begin{array}{c}\text { Colom et al., } \\
2003\end{array}$} \\
\hline & CCCCGAAGAACGTTTTC & & \\
\hline \multirow[t]{2}{*}{$q n r \mathrm{~A}$} & ATTTCTCACGCCAGGATTTG & \multirow[t]{2}{*}{$516 \mathrm{bp}$} & \multirow{2}{*}{$\begin{array}{c}\text { Robicsek } e t \\
\text { al., } 2006\end{array}$} \\
\hline & GATCGGCAAAGGTTAGGTCA & & \\
\hline \multirow[t]{2}{*}{$\operatorname{aadB}$} & GAGCGAAATCTGCCGCTCTGG & \multirow[t]{2}{*}{$319 \mathrm{bp}$} & \multirow{4}{*}{$\begin{array}{c}\text { Franaet al., } \\
2001\end{array}$} \\
\hline & CTGTTACAACGGACTGGCCGC & & \\
\hline \multirow[t]{2}{*}{ tetA (A) } & GGTTCACTCGAACGACGTCA & \multirow[t]{2}{*}{$576 \mathrm{bp}$} & \\
\hline & CTGTCCGACAAGTTGCATGA & & \\
\hline
\end{tabular}


Table (2): Cycling conditions of the different primers during $c P C R$

\begin{tabular}{|c|c|c|c|c|c|c|}
\hline Gene & $\begin{array}{c}\text { Primary } \\
\text { denaturati } \\
\text { on }\end{array}$ & $\begin{array}{c}\text { Secondary } \\
\text { denaturati } \\
\text { on }\end{array}$ & $\begin{array}{c}\text { Anneali } \\
\text { ng }\end{array}$ & $\begin{array}{c}\text { Extensi } \\
\text { on }\end{array}$ & $\begin{array}{c}\text { No. } \\
\text { of } \\
\text { cycle } \\
\text { s }\end{array}$ & $\begin{array}{c}\text { Final } \\
\text { extensio } \\
\text { n }\end{array}$ \\
\hline bla $\mathrm{TE}$ & $94^{\circ} \mathrm{C}$ & $94^{\circ} \mathrm{C}$ & $54^{\circ} \mathrm{C}$ & $72^{\circ} \mathrm{C}$ & 35 & $72^{\circ} \mathrm{C}$ \\
$\mathrm{M}$ & $5 \mathrm{~min}$. & $30 \mathrm{sec}$. & $40 \mathrm{sec}$ & $45 \mathrm{sec}$ & & $10 \mathrm{~min}$. \\
\hline qnr $\mathrm{A}$ & $94^{\circ} \mathrm{C}$ & $94^{\circ} \mathrm{C}$ & $55^{\circ} \mathrm{C}$ & $72^{\circ} \mathrm{C}$ & 35 & $72^{\circ} \mathrm{C}$ \\
& $5 \mathrm{~min}$. & $30 \mathrm{sec}$. & $40 \mathrm{sec}$ & $45 \mathrm{sec}$ & & $10 \mathrm{~min}$. \\
\hline aad $\mathrm{B}$ & $94^{\circ} \mathrm{C}$ & $94^{\circ} \mathrm{C}$ & $58^{\circ} \mathrm{C}$ & $72^{\circ} \mathrm{C}$ & 35 & $72^{\circ} \mathrm{C}$ \\
& $5 \mathrm{~min}$. & $30 \mathrm{sec}$. & $30 \mathrm{sec}$. & $30 \mathrm{sec}$. & & $7 \mathrm{~min}$. \\
\hline tet $\mathrm{A}(\mathrm{A}$ & $94^{\circ} \mathrm{C}$ & $94^{\circ} \mathrm{C}$ & $50^{\circ} \mathrm{C}$ & $72^{\circ} \mathrm{C}$ & 35 & $72^{\circ} \mathrm{C}$ \\
) & $5 \mathrm{~min}$. & $30 \mathrm{sec}$. & $40 \mathrm{sec}$ & $45 \mathrm{sec}$ & & $10 \mathrm{~min}$. \\
\hline
\end{tabular}

Results:

It was clear in table (3) that all salmonellae were sensitive to amikacin, norfloxacin, ciprofloxacin except $S$. Takoradi resistant to ciprofloxacin. All salmonellae were sensitive to enrofloxacin except $S$. Kentucky, $S$. Tamale \& S. Molade. However, all salmonellae were resistant to flumequine except $S$. Typhimurium, $S$. Tamale, $S$. Molade \& $S$. Inganda. All examined salmonellae were sensitive to amoxicillin except $S$. Typhimurium, $S$. Newport, $S$. Tamale\& $S$. Enteritidis. However, all examined salmonellae were resistant to ampicillin except $S$. Typhimurium, $S$. Kentucky , $S$. Newport\& $S$. Enteritidis. All salmonellae were sensitive to neomycin except $S$. Kentucky, $S$. Newport, $S$. Enteritidis\& $S$. Inganda. Also, all salmonellae were sensitive to gentamycin except $S$. Typhimurium, $S$. Enteritidis\& $S$. Takoradi. All salmonellae were resistant to doxycycline hydrochloride except $S$. Kentucky\& $S$. Takoradi sensitive to doxycycline.

Five Salmonella isolates were examined by PCR for qnrA gene (a resistant gene for quinolones) while other Salmonella isolates not examined for this gene as they were sensitive to quinolones. All isolates were positive for this gene giving amplification of $516 \mathrm{bp}$ fragments. Also, the positive control showed 516 bp fragments whereas no amplification could be observed with the negative control as shown in table (4) and figure (1).

Nine Salmonella isolates were examined by PCR for blaTEM gene (a resistant gene for $\beta$ Lactamases) while other isolates not examined by PCR as they were sensitive to $\beta$ Lactamas. Nine isolates (100\%) were positive for this gene giving amplification of $516 \mathrm{bp}$ fragments. Also the positive control showed 516 bp fragments whereas no 
amplification could be observed with the negative control as in table (4) and figure (2).

Seven Salmonella isolates were examined by PCR for tetA (A) gene (a resistant gene for tetracycline) while other isolates not examined for this gene as they were sensitive to doxycycline. All isolates $(100 \%)$ were positive for this gene giving amplification of $576 \mathrm{bp}$ fragments. Also the positive control showed $576 \mathrm{bp}$ fragments whereas no amplification could be observed with the negative control as in table (4) and figure (3).

Three Salmonella isolates were examined by PCR for $a a d \mathrm{~B}$ gene (a resistant gene for gentamycin) whiles other Salmonella isolates not examined for this gene as they were sensitive to gentamycin. All isolates $(100 \%)$ were negative for this gene whereas no amplification at $319 \mathrm{bp}$ fragments. The positive control showed 319 bp fragments whereas no amplification could be observed with the negative control as in table (4) and figure (4).

Table (3) Results of antibiotic sensitivity tests

\begin{tabular}{|c|c|c|c|c|c|c|c|c|c|c|}
\hline$\underbrace{\text { Antibiotic discs }}_{\text {Strains }}$ & CIP & ENR & $\begin{array}{c}\text { NO } \\
\text { R }\end{array}$ & UB & $\underset{\mathbf{X}}{\mathbf{A M}}$ & $\underset{\mathbf{P}}{\mathbf{A M}}$ & $\mathbf{N}$ & $\begin{array}{l}\mathbf{C} \\
\mathbf{N}\end{array}$ & $\begin{array}{l}\mathbf{A} \\
\mathbf{K}\end{array}$ & DO \\
\hline $2 S$. Typhimurium & $S$ & I & S & I & $\mathrm{R}$ & I & I & $\mathrm{R}$ & $\mathrm{S}$ & $\mathrm{R}$ \\
\hline S. Kentucky & I & $\mathrm{R}$ & $S$ & $\mathrm{R}$ & I & $\mathrm{S}$ & $\mathrm{R}$ & S & S & I \\
\hline S. Newport & $S$ & I & $S$ & $\mathrm{R}$ & $\mathrm{R}$ & $S$ & $\mathrm{R}$ & I & $\mathrm{S}$ & $\mathrm{R}$ \\
\hline S. Tamale & I & $\mathrm{R}$ & I & S & $\mathrm{R}$ & $\mathrm{R}$ & I & $S$ & S & $\mathrm{R}$ \\
\hline$S$. Enteritidis & I & I & $\mathrm{S}$ & $\mathrm{R}$ & $\mathrm{R}$ & $\mathrm{S}$ & $\mathrm{R}$ & $\mathrm{R}$ & S & $\mathrm{R}$ \\
\hline S. Molade & I & $\mathrm{R}$ & $S$ & I & $S$ & $\mathrm{R}$ & $\mathrm{S}$ & I & I & $\mathrm{R}$ \\
\hline S. Takoradi & $\mathrm{R}$ & I & $\mathrm{S}$ & $\mathrm{R}$ & I & $\mathrm{R}$ & I & $\mathrm{R}$ & $\mathrm{S}$ & I \\
\hline S. Virchow & $S$ & I & S & $\mathrm{R}$ & I & $\mathrm{R}$ & S & I & S & $\mathrm{R}$ \\
\hline S. Inganda & $S$ & I & S & I & $S$ & $\mathrm{R}$ & $\mathrm{R}$ & $S$ & $S$ & $\mathrm{R}$ \\
\hline
\end{tabular}

$\mathrm{R}=$ resistant, $\mathrm{S}=$ sensitive, $\mathrm{I}=$ intermediately sensitive, $\mathrm{CIP}=$ Ciprofloxacin, $\mathrm{ENR}=$ Enrofloxacin, $\mathrm{NOR}=$ Norfloxacin, $\mathrm{UB}=$ Flumequine, $\mathrm{AMX}=$ Amoxicillin, $\mathrm{AMP}=$ Ampicillin, $\mathrm{N}=$ Neomycin, $\mathrm{CN}=$ Gentamycin, $\mathrm{AK}=$ Amikacin, DO= Doxycycline hydrochloride 
Table (4) Results of Polymerase Chain Reaction technique for different resistant genes from the examined isolates.

\begin{tabular}{|c|l|c|c|c|c|}
\hline Sample & \multicolumn{1}{|c|}{ Serovar } & qnrA & blaTEM & tetA(A) & $\boldsymbol{a a d B}$ \\
\hline 1 & S. Kentucky & + & $\mathrm{Nd}$ & $\mathrm{Nd}$ & $\mathrm{Nd}$ \\
\hline 2 & S. Tamale & + & + & + & $\mathrm{Nd}$ \\
\hline 3 & S. Inganda & $\mathrm{Nd}$ & + & + & $\mathrm{Nd}$ \\
\hline 4 & S. Typhimurium & $\mathrm{Nd}$ & + & + & - \\
\hline 5 & S. Newport & $\mathrm{Nd}$ & + & + & $\mathrm{Nd}$ \\
\hline 6 & S. Molade & + & + & + & $\mathrm{Nd}$ \\
\hline 7 & S.Typhimurium & + & + & $\mathrm{Nd}$ & $\mathrm{Nd}$ \\
\hline 8 & S. Enteritidis & $\mathrm{Nd}$ & + & + & - \\
\hline 9 & S. Takoradi. & + & + & $\mathrm{Nd}$ & - \\
\hline 10 & S. Virchow & $\mathrm{Nd}$ & + & + & $\mathrm{Nd}$ \\
\hline
\end{tabular}

$\boldsymbol{q n} \boldsymbol{r} \boldsymbol{A}=$ resistant genes for quinolones, $\boldsymbol{b l a} \boldsymbol{T E M}=$ resistant genes for Blactamases, $\boldsymbol{t e t} \boldsymbol{A}(\boldsymbol{A})=$ resistant gene for doxycycline, $\boldsymbol{a} \boldsymbol{a d} \boldsymbol{B}=$ resistant gene for gentamycin, $\mathrm{Nd}=$ not examined by $\mathrm{PCR}=$ sensitive samples.

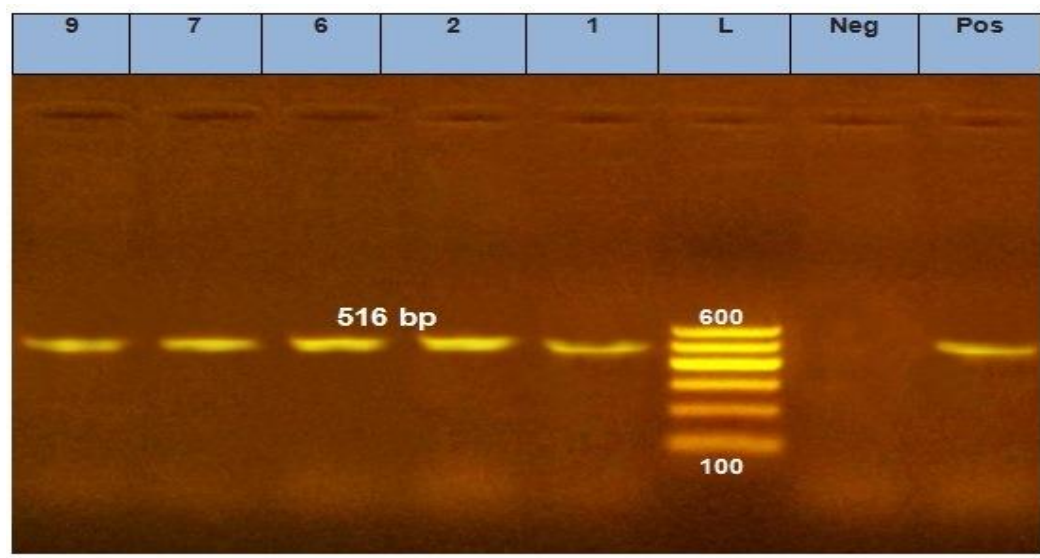

Figure (1): Agarose gel electrophoresis showing specific PCR of Salmonella isolates using primer set for $q n r \mathrm{~A}$ gene $(516 \mathrm{bp})$. Lane $\mathrm{L}=$ ladder (100-600 bp). $\mathrm{Pos}=$ positive control. Neg= negative control. Lane 1: $S$. Kentucky. Lane 2: S. Tamale. Lane 6: $S$. Molade. Lane 7: $S$. Typhimurium. Lane 9: $S$. Takoradi. 


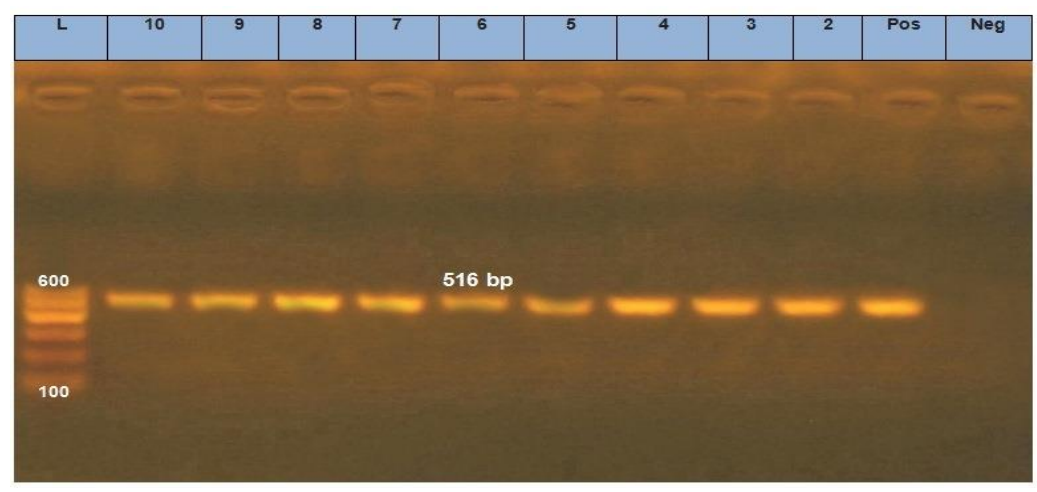

Figure (2): Agarose gel electrophoresis showing specific PCR of Salmonella isolates using primer set for blaTEM gene (516 bp). L: ladder (100-600 bp). Pos.: Positive control. Neg.: Negative control. Lane 2: S. Tamale. Lane 3: $S$. Inganda. Lane 4: $S$. Typhimurium. Lane 5: $S$. Newport. Lane 6: $S$. Molade. Lane 7: $S$. Typhimurium. Lane 8: S. Enteritidis. Lane 9: $S$. Takoradi. Lane10: $S$. Virchow.

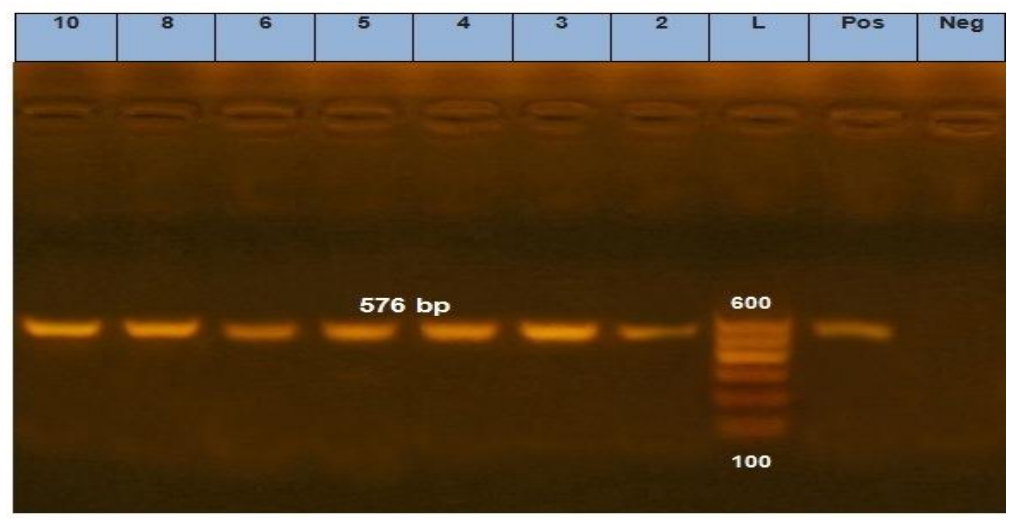

Figure (3): Agarose gel electrophoresis showing specific PCR of Salmonella isolates using primer set for tetA(A) gene (576 bp). L=ladder (100-600 bp).Pos.: Positive control. Neg.: Negative control. Lane 2: $S$. Tamale. Lane 3: $S$. Inganda. Lane 4: $S$. Typhimurium. Lane 5: $S$. Newport. Lane 6: $S$. Molade. Lane 8: S. Enteritidis. Lane10: S. Virchow. 


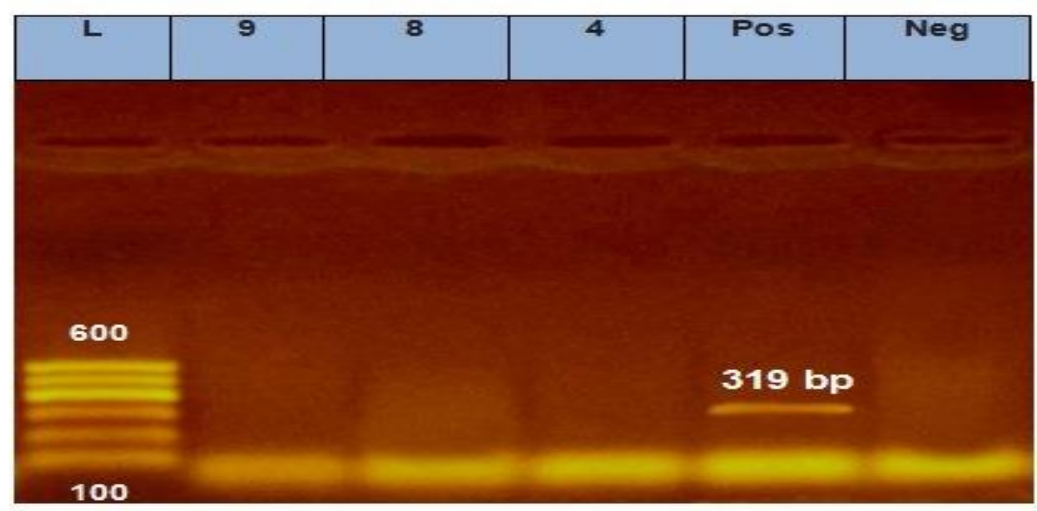

Figure (4): Agarose gel electrophoresis showing specific PCR of Salmonella isolates using primer set for $a a d \mathrm{~B}$ gene (319bp). $\mathrm{L}=\operatorname{ladder}(100-600 \mathrm{bp}$ ). Pos.: Positive control. Neg.: Negative control. Lane 4: S. Typhimurium. Lane 8: $S$. Enteritidis. Lane 9: $S$. Takoradi.

\section{Discussion:}

In this study, all strains were sensitive to amikacin and norfloxacin (100\%) which was the most effective chemotherapeutic agent against Salmonella infection which is in parallel with the result recorded by (Snow et al., 2007) who reported sensitivity to amikacin was $(100 \%)$ and Shivhare et al. (2000) who recorded highest sensitivity of Salmonella isolated from poultry to norfloxacin was 92\%. Also, higher rates of sensitivity were observed to ciprofloxacin (89\%) and streptomycin (77.7\%) and this nearly agree with Habrun et al. (2012) who reported that all Salmonella isolates were sensitive to streptomycin (100\%). However, Hussain et al. (2010) and Cardoso et al. (2006) found that higher resistance to streptomycin $(92.10 \%)$. The rise in resistance to gentamicin and norfloxacin is of concern, as these drugs are often considered in the treatment and control of several poultry diseases. PCR was a perfect tool for accurate detection of Salmonella resistant genes and the results that qnrA gene a resistant gene for quinolones were reported in all examined isolates with a percentage of $(100 \%)$. The results obtained for qnrA gene disagree with Kees et al. (2008). It is admitted that resistance to quinolones results from both chromosomal and plasmid-mediated quinolone resistance (PMQR) mechanisms. Qnr genes represent one of the most important PMQR mechanisms. These genes encode pentapeptide repeat proteins that block the action of ciprofloxacin (CIP) on bacterial DNA gyrase and topoisomerase IV Tran and Jacoby (2002). Three major groups of qnr 
determinants have been described (qnrA, qnrB, and $q n r \mathrm{~S})$, which share between $40 \%$ and $60 \%$ similarity Strahilevitz et al. (2009).

The blaTEM gene, a gene encoded for B- lactamases resistance was reported in the present study with a percentage of $100 \%$ and these results nearly in coordinated with Hur et al. (2011) who reported that 19 out of the 21 penicillin resistant $S$. Enteritidis in Korea carried the bla(TEM) gene with a percentage of (90.5\%). However, Ahmed et al. (2009) found the percentage of bla(TEM-1) was $10 \%$ which was identified in between10 Salmonella isolates from retail chicken meat in Hiroshima, Japan. While, El-Sharkawy et al. (2017) reported that $65.5 \%$ of $S$. Enterica serovars Typhimurium were harboured ampicillin (BlaTEM).

The tetA (A) gene, a gene encoded for tetracycline resistance was reported in the present study with a percentage of $100 \%$ these results agree with Yemisi et al. (2014) who reported that all of the 20 TETresistant Salmonella isolates carried tetA gene (100\%) and 30\% (6), 35\% (7), and $50 \%$ (10) of the isolates carried tet $\mathrm{B}$, tet $\mathrm{C}$, and tet $\mathrm{G}$ genes, respectively and these results nearly in coordinated with $\mathbf{L u}$ et al. (2011) who reported that $108 \mathrm{~S}$. Indiana possessed tetA gene with a percentage of $81.2 \%$ and Shahada et al. (2006) who reported that $89 \%$ of oxytetracycline-resistant $S$. Infantis from poultry in Japan carried the $\operatorname{tet}(\mathrm{A})$ gene. Moreover,
El-Sharkawy et al. (2017) found that $84.5 \%$ of $S$. Enterica serovars Typhimurium and $50 \%$ of $S$. Enterica serovars Enteritidis isolates were harboured. The $a a d \mathrm{~B}$ gene, a gene encoded for gentamycin resistance was abscence in the present study with a percentage of $100 \%$ and this result agree with a study performed by El-Sharkawy et al. (2017) who reported that $a a d \mathrm{~B}$ and $a a c \mathrm{C}$ (gentamycin resistance) were not amplified in all screened isolates.

\section{References:}

Ahmed, A.M.; Shimabukuro, H. and Shimamoto, T. (2009): Isolation and molecular characterization of multidrugresistant strains of Escherichia coli and Salmonella from retail chicken meat in Japan.J. Food Sci. 74 (7): M 405-410.

Cardoso, M.O.; Ribeiro, A.R.; Santos, L.R.; Pilotto, F.; Moraes, H.L.S.; Salle, C.T.P.; Rocha, S.L.S. and Nascimento, V.P. (2006): Antibiotic resistance in Salmonella Enteritidis isolated from broiler carcasses. Braz. J. Microbiol.; 37: 368-371.

El-Sharkawy, Hanem; Amin, Tahoun; Abd El-Galiel, A. ElGohary; Moshira, El-Abasy; Fares, El-Khayat; Trudi, Gillespie; Yukio, Kitade; Hafez, M. Hafez; Heinrich, Neubauer and Hosny, El-Adawy (2017): Epidemiological, molecular characterization and antibiotic 
resistance of Salmonella enterica serovars isolated from chicken farms in Egypt. Gut Pathogens, 9: 8.DOI 10.1186/s13099-017-0157-1.

Finegold, S. M. and Martin, E. T. (1982): Diagnostic microbiology. 6th Ed., The C.V. Mosby Company, St. Louis, Toronto, London.

Gallegos, R.; Loredo, A.; Ojeda, G. and Vega, A. (2008): Identification of Salmonella serotypes isolated from cantaloupe and chile pepper production system in Mexico using PCR-RFLP. J. Food Protect., 71(11): 2217-2222.

Habrun, B.; Simpraga, B.; Kompes, G. and Krstulovic, F. (2012): Antimicrobial resistance and serotyping of Salmonella entericasubsp. enterica isolated from poultry in Croatia. VeterinarskiArhiv;. 82 (4): 371-381. Hur, J.; Kim, J.H.; Park, J.H.; Lee, Y.J. and Lee, J.H. (2011): Molecular and virulence characteristics of multidrug resistant Salmonella Enteritidis strains isolated from poultry. Vet $\mathrm{J}$; 189(3):306-311.

Hussain, Soomro, Aijaz; Muhammad, Khaskheli; Muhammad, Bachal, Bhutto; Ghiasuddin, Shah; Azizullah, Memon and Parkash, Dewani (2010): Prevalence and antimicrobial resistance of Salmonella serovars isolated from poultry meat in Hyderabad, Pakistan.Turk. J. Vet. Anim. Sci.; 34(5): 455-460.
ISO 6579 (2002): Microbiology of food and animal feeding stuffshorizontal method for the detection of Salmonella Spp. International standard. (Fourth edition) (200207- 15).

Kees, Veldman; Wilfrid, van Pelt and Dik, Mevius (2008): First report of qnr genes in Salmonella in The Netherlands. Journal of Antimicrobial Chemotherapy (2008) 61, 452-463

Lu, Y.; Wu, C.M.; Wu, G.J.; Zhao, H.Y.; He, T.; Cao, X.Y.; Dai,L.; Xia, L.N.; Qin, S.S. and Shen, J.Z. (2011): Prevalence of antimicrobial resistance among Salmonella isolates from chicken in China. Food borne Pathog. Dis.; 8(1):45-53.

Nikaido H. (2009): Multidrug resistance in bacteria. Annu Rev Biochem. 2009; 78:119.

Quinn, P.J.; B.K. Markey; M.E. Carter; W.J. Donnelly and F.C. Leonard (2002): Veterinary Microbiology and Microbial Diseases. 1st Edn., WileyBlackwell Science, USA., 544-549.

Robicsek, A.; Strahilevitz, J.; Sahm, D.F.; Jacoby, G.A. and Hooper, D.C. (2006): $q n r$ prevalence in ceftazidime-resistant Enterobacteriaceae isolates fromthe United States. Antimicrob Agents Chemother 50:2872-2874.

Sambrook, J.; Fritscgh, E.F. and Mentiates (1989): Molecular coloning. A laboratory manual. Vol. I, Cold spring Harbor Laboratotry press, New York. 
Shahada, F.; Chuma, T.; Tobata, T.; Okamoto, K.; Sueyoshi, M.andTakase, K. (2006): Molecular epidemiology of antimicrobial resistance among Salmonella enterica serovar Infantis from poultry in Kagoshima, Japan. Int. J. Antimicrob. Agents.28(4):302-307.

Shivhare, S.; Sharda, R.; Reddy, A.; Sharma, R. and Sharma, V.(2000): Antibiotic sensitivity of Salmonella Typhimurium isolatesfrom domestic poultry. Ind. Vet. J., 77 (11): 998 -999.

Snow, L. C.; Davies, R. H.; Christiansen, K. H.; CarriqueMas, J.J.; Wales, A. D.; O'Connor, J. L.; Cook, A. J. C. and Evans, S.J. (2007): Survey of the prevalence of Salmonella species oncommercial laying farms in the United Kingdom. VeterinaryRecord 161:471-476.

Strahilevitz, J., Jacoby, G.A., Hooper, D.C. and Robicsek, A. (2009):

Plasmid-mediated quinolone resistance: A multifaceted threat. Clin. Microbiol. Rev., 22: 664-689.

Tosini, F.; Visca, P.; Luzzi, I.; Dionisi, A.M.; Pezzella, C. and Petrucca, A. (1998): Class I integron-borne multiple-antibiotic resistance carried by IncF1 and IncL/M plasmids in Salmonella enterica serotype Typhimurium. Antimicrob Agents Chemother 1998; 42:3053-8.

Tran, J.H. and Jacoby, G.A. (2002): Mechanism of plasmidmediated quinolone resistance. Proc. Natl. Acad. Sci. USA, 99: 5638-5642.

Yemisi, O. Adesiji; Vijaya, Kumar, Deekshit and Indrani, Karunasagar (2014): Antimicrobial-resistant genes associated with Salmonella spp. isolated from human, poultry, and seafood sources. Food Science \& Nutrition published by Wiley Periodicals, Inc. 
الكثف عن بعض الجينات المقاومة للمضادات الحيوية داخل عترات السالمونيلا

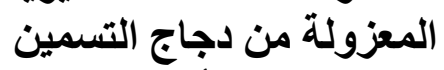

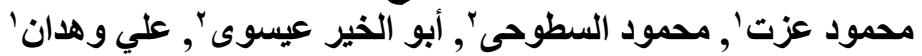

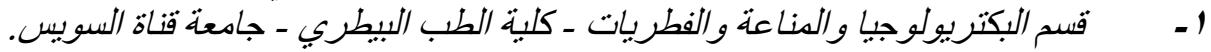

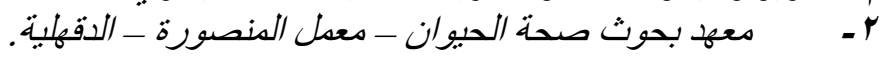

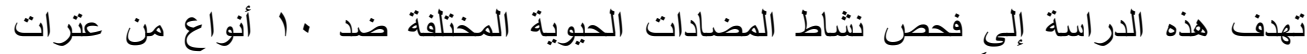

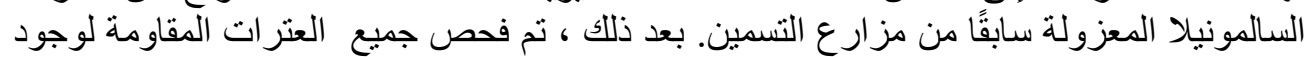

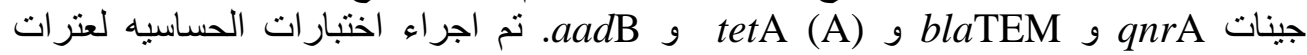

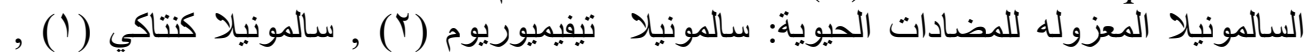

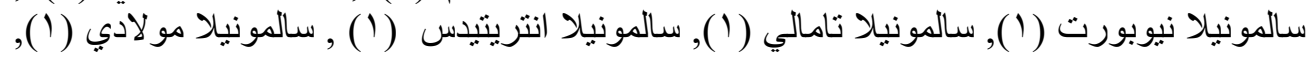

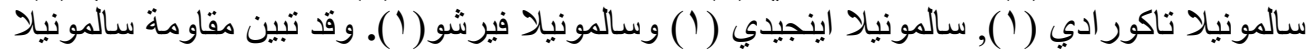

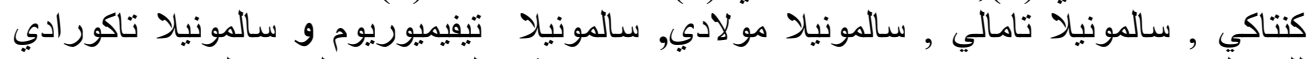

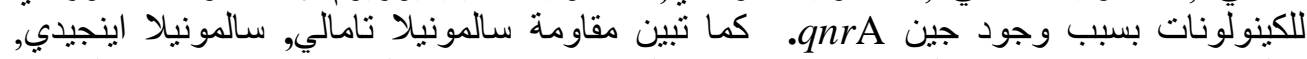

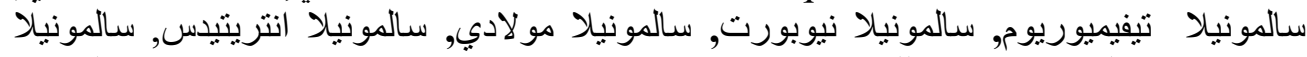

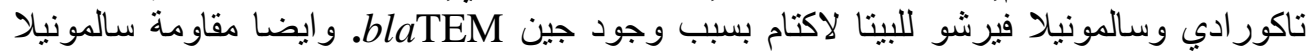

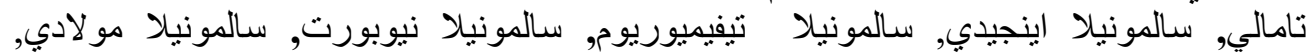

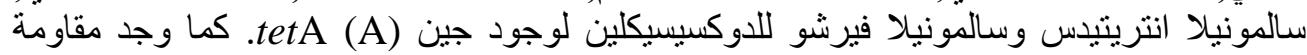

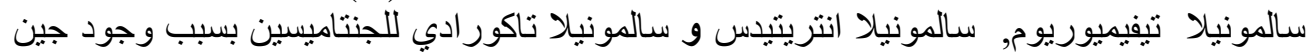

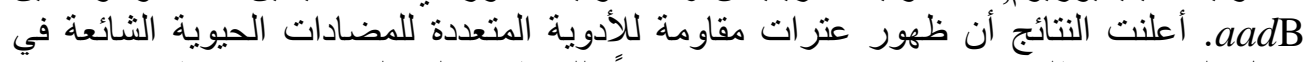

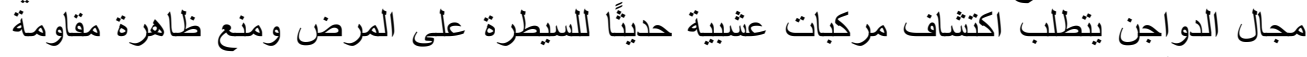

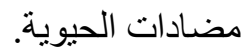

